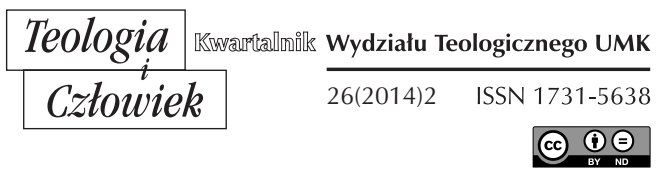

KS. PIOTR GÓRSKI*

\title{
SPRAWOZDANIE Z 45 SYMPOZJUM JÓZEFOLOGICZNEGO \\ W KALISZU
}

DOI: http://dx.doi.org/10.12775/TiCz.2014.026

Święty Józef - Opiekun Zbawiciela. 25 lat adhortacji Jana Pawta II Redemptoris custos. Pod tym hasłem w dniu 10 maja 2014 roku odbyło się 45. Sympozjum Józefologiczne w Kaliszu. Spotkanie rozpoczęło się tradycyjnie Eucharystią w Bazylice św. Józefa, której przewodniczył Biskup Kaliski Edward Janiak. Ksiądz Biskup w swojej homilii nawiązał do wielu wydarzeń historycznych związanych z obrazem św. Józefa Kaliskiego, takich jak zniszczenie świątyni w 1783 roku, w trakcie którego ołtarz św. Józefa cudownie ocalał. Biskup przypomniał piękny moment koronacji obrazu 15 maja 1796 roku, w którym uczestniczyło ok 80 tyś. wiernych. Pasterz odwołał się również do współczesnego wydarzenia, jakim było przekazanie pierścienia przez papieża Franciszka w dniu 19 marca 2014 roku.

Po Eucharystii wszyscy uczestnicy sympozjum przenieśli się do budynku Polskiego Centrum Józefologicznego. Obrady rozpoczął prezes ks. dr Andrzej Latoń, który podkreślił olbrzymią wagę papieskiej

* Ks. dr Piotr Górski jest prezbiterem diecezji kaliskiej i pracuje w parafii Świętej Rodziny w Kaliszu. 
adhortacji, która nadal jest niedoceniana, także w kręgach naukowych. Ks. Andrzej wskazał, że szansą, by nauka o Józefie wychodziła na światło dzienne z pewnością może być kanonizacja Jana XXIII i Jana Pawła II, dwóch wielkich papieży oddanych św. Józefowi.

Pierwszym prelegentem była Sandra de Arriba Cantero z Hiszpanii, pracująca na Uniwersytecie Valladolid. Prelegentka wygłosiła wykład pod tytułem: Święty Józef i Dzieciątko: czułość pomiędzy ojcem i synem $w$ sztuce barokowej. Prezentując różnego rodzaju przedstawienia św. Józefa $\mathrm{w}$ ikonografii i sztuce, autorka unaoczniła pewnego rodzaju ignorancję wobec Cieśli z Nazaretu, który często był pomijany w ikonografii bizantyjskiej lub ukazywany w sposób niewłaściwy. Józef przedstawiany był jako odwrócony do żłóbka, osamotniony. W sztuce gotyckiej czasami przypisywano mu funkcje, które pełniła Maryja. Prelegentka wskazała, że dopiero barok zaczął ukazywać Józefa we właściwy sposób. Poprzez odwoływanie się do ikonografii maryjnej, poprzez pewną analogię zaczęto ukazywać czułą i ojcowską miłość Józefa. Te przedstawienia mają wyraźny rys miłości silnej, dającej poczucie bezpieczeństwa, a jednocześnie nie deprecjonuje się $\mathrm{w}$ nich elementu uczuciowego.

Kolejny referat pt.: Ukrzyżowanie św. Józefa wygłosił prof. Jan Grosfeld z UKSW w Warszawie. Na początku autor, sięgając do tradycji żydowskiej, zauważył, że kto słucha Słowa Bożego, ten jest jak król. Taki człowiek zaczyna rozumieć historię, tak jak Bóg. Autor odniósł się do znanego tekstu z Księgi Powtórzonego Prawa: Stuchaj, Izraelu: Pan jest naszym Bogiem, Panem jedynym. Ten tekst wskazuje, że należy miłować Boga całym sercem, umysłem i ze wszystkich sił. Izrael poprzez całą swoją historię był prowadzony, aby zrealizować w sobie ten rodzaj wiary w Boga, poprzez ukrzyżowanie swojego serca, umysłu i samego siebie. Realizację tej miłości w pełni możemy odnaleźć w Jezusie Chrystusie, w Jego ukrzyżowaniu ciała, serca i umysłu. Wskazał, że również w życiu Józefa możemy odnaleźć podobne elementy ukrzyżowania. Ten Patriarcha aby wypełnić plan Boga, musiał ukrzyżować swoje serce, umysł i ciało. Józef mógł to uczynić właśnie poprzez zasłuchanie się w wolę Boga.

Referatem "Nieobecna obecność" Świętego Józefa w liturgii rozpoczął sesję popołudniową ksiądz prof. Krzysztof Konecki z Uniwersytetu Mikołaja Kopernika w Toruniu. Prelegent podkreślił ciągłą dysproporcję pomiędzy kultem maryjnym a kultem św. Józefa. Tę szczególną dysharmonię da się zauważyć przede wszystkim w takich księgach liturgicznych, jak Mszał rzymski i Liturgia godzin. Ksiądz profesor na 
potwierdzenie swojej tezy wskazał takie przykłady, jak święto Ofiarowania Pańskiego, które obchodzimy 2 lutego. Jest sprawą oczywistą, że w wydarzeniu Ofiarowania Pańskiego Józef miał bardzo ważny udział. To on jako ojciec wraz z Maryją dokonał tego obrzędu. Kiedy jednak sięgamy do formularza mszalnego związanego z tym wydarzeniem, Józef jest tam nieobecny. Liturgia godzin z tego święta również pozostawia wiele do życzenia. Józef jest tam obecny jedynie w dwóch antyfonach. Jeszcze większy problem możemy - zdaniem księdza profesora - dostrzec w okresie adwentu, gdzie tak naprawdę nie mówi się w ogóle o osobie Patriarchy z Nazaretu. Nasz prelegent zaznaczył, że ta nieobecność jest niezrozumiała i wymaga koniecznej korekty.

Kolejne przedłożenie, Święty Józef: Robotnik w Winnicy Pańskiej na przykładzie pism św. Edyty Stein, zaprezentował ks. Ryszard Dyc. Prelegent ukazał różne przestrzenie pracy Józefa, o których możemy powiedzieć, że są pracą w Winnicy Pańskiej. Tego rodzaju zaangażowanie możemy porównać do pracy samego Boga, który uprawia Winnicę. Posługa Józefa staje się niejako przedłużeniem działania samego Boga, gdyż Józef zajmował się wychowaniem Jezusa, a jego posługa zostaje przedłużona w tajemnicy Kościoła, który jest mistycznym ciałem Jezusa. Zdaniem księdza Dyca ta rzeczywistość pracy Józefa w Winnicy w sensie duchowym uobecnia się w Karmelu. W tekstach Edyty Stein czytamy, że Karmel jest porównywany do Winnicy Pańskiej. W duchowość karmelitańską mocno wpisuje się św. Józef, który stanowi wzór czerpania radości ze szczególnej służby Bogu, ale także uczy, jak łączyć przestrzeń życia duchowego $\mathrm{z}$ tym, co doczesne.

Ostatni referat Tajemnica ojcostwa Śziętego Józefa w świetle adhortacji Redemptoris custos Jana Pawła II, wygłosił ks. Piotr Górski. Prelegent wskazal, że ojcostwo Józefa nie jest czymś dodatkowym, ale że Bóg przewidział to ojcostwo w sposób bezpośredni ze względu na tajemnicę wcielenia. Obecność Patriarchy nie jest tu jakąś koniecznością rzeczową, ale Bóg chciał ojcostwa Józefa właśnie ze względu na pełnię tajemnicy wcielenia. Adhortacja Redemptoris custos, oprócz tego, że wskazuje na niezwykłą wagę małżeństwa Józefa i Maryi, podkreśla również, że w planie Boga zarówno ojcostwo, jak i macierzyństwo zostało przewidziane w sposób bezpośredni ze względu na osobę Jezusa Chrystusa. Dokument papieski wymienia cały szereg tajemnic życia ukrytego Jezusa, w których Patriarcha z Nazaretu wypełnił swoją niezastąpioną misje. Te misteria mają charakter niejako sakramentalny, a Józef uczestniczy w nich w spo- 
sób wewnętrzny. Nie jest on tylko biernym obserwatorem, ale bierze czynny udział w misteriach zbawczych ukrytego życia Jezusa. Na końcu prelegent podkreślił, że ojcostwo Józefa jest ojcostwem ikonicznym, które odsłania ojcostwo Boga.

Sympozjum zgromadziło liczną grupę słuchaczy, nie tylko z Kalisza, ale również z całej Polski. Cieszy fakt, że coraz więcej osób, również na płaszczyźnie naukowej, odkrywa niezwykłą wartość józefologii, która staje się nieodłączną dziedziną teologii dogmatycznej. 